\title{
Environmentally Induced Cracking of API Grade Steel in Near-Neutral pH Soil
}

\author{
J. A. C. P. Gomes \\ ponciano@metalmat.ufrj.br \\ Federal University of Rio de Janeiro - UFRJ \\ Rio de Janeiro, RJ, Brazil
}

Environmentally induced cracking of pipeline steels in contact with soil have been investigated. Different soils were prepared in order to determine their physical, chemical and bacteriological characteristics. Slow strain rate testing was carried out by using electrolytes obtained from soil samples and NS4 standard solution. Stress vs. strain curves of API 5L grade X46, X60 and X80 steels were obtained at different electrode potentials (Ecorr, $100 \mathrm{mV}$ below Ecorr and $300 \mathrm{mV}$ below Ecorr) with $9 \times 10-6 \mathrm{~s}$-1 strain rate. The results obtained with API $5 L$ X46 in soil solution were compared with slow strain rate test (SSRT) results obtained using a strain rate of $9 \times 10-7 \mathrm{~s}-1$ to the same steel. All results showed the incidence of cracking and their dependence on the potential imposed, revealing the SCC (Stress corrosion cracking) susceptibility of the steels. It was also observed that the hydrogen embrittlement - HE - has an important contribution to cracking initiation and propagation. Cracking morphology was similar to the SCC reported on field condition where transgranular cracking were detected in a pipeline collapsed by land creeping. It was important to point out that even under cathodic potentials the material showed the incidence of secondary cracking and a significant reduction of ductility.

Keywords: buried pipelines, soil, environmentally induced cracking, transgranular cracking

\section{Introduction}

External cracking of pipelines is consequence of complex interactions between physical and chemical factors (Gomes et al., 2005). Moreover, this cracking can occur during the pipeline service life, if the pipe is under the influence of mechanical stresses. In that case, there are different types of stresses, such as residual stress that is induced by welding procedures and applied stress that is influenced by operational pressure or soil movement. Based on the failure analysis of the pipe cracking, some authors concluded that excessive soil movement was responsible for the coating rupture and the incidence of cracking at a buried pipeline (Souza and Olivier, 2002).

Researchers consider that the cracking process related to external SCC (Stress corrosion cracking) in contact with soil is associated to hydrogen embrittlement (HE). However, basic aspects of this mechanism are not fully understood (Gabeta et al., 2001; Parkins et al., 1994; Zheng, 1996; GRI, 1998; Benmoussa et al., 2006). The main parameter considered by the authors is the $\mathrm{pH}$ of the soil. Furthermore, it can process by two types of cracking morphology: transgranular cracking (TGSCC) or intergranular cracking (IGSCC).

Considering the hypothesis that the steel composition and steel mechanical resistance do not affect the cracking morphology, this author concludes that the incidence of TGSCC or IGSCC will be related to the characteristics of the corrosive environment. Then, IGSCC would be associated to relatively concentrated carbonatebicarbonate solutions with $\mathrm{pH}$ values close to 9.5. Consequently, IGSCC is commonly referred as high pH SCC (Parkins et al., 1994).

In addition, other authors (Wang and Atrens, 2003) relate that crack propagation for the high $\mathrm{pH} \mathrm{SCC}$ is mostly intergranular along ferrite: ferrite $(\alpha: \alpha)$ grain boundaries (GBs). Then, when the crack tip meets a perlite colony, it may be deflected or it may propagate through the perlite colony in a transgranular manner. The IGSCC propagation of ferrite steels (including pipeline steels) is attributed to a dissolution mechanism.
On the other hand, TGSCC occurs in the presence of relatively diluted solutions with $\mathrm{pH}$ values of 6.5 , called as near neutral $\mathrm{pH}$ SCC. Therefore, the classification of SCC is based on the nature of the environment (acidic or alkaline) in contact with external surface of a pipeline.

Another determining factor for IGSCC or TGSCC could be the electrochemical potential, because the potential would determine the reaction mechanism and the products formed in each condition. For instance, it is assumed that TGSCC is associated with the formation of iron carbonate between the coating and the metallic surface. On another point, when IGSCC occurs, only a low amount of iron carbonate is eventually incorporated to a predominant thin film of magnetite. The author also suggests that the mechanism of TGSCC involves hydrogen embrittlement and depends on hydrogen uptake and permeation from the environment (Parkins et al., 1994).

There is an alternative interpretation of IGSCC and TGSCC. According to this author, TGSCC depends on the hydrogen permeation at the crack tip. Cracking nucleation and propagation would be much more influenced by the mechanical loading conditions at the crack tip. Consequently, the influence of the chemical solution would be secondary. The authors describe that the terminology "low pH SCC" used to indicate transgranular external cracking, would be inadequate and could be considered as a misleading indication. After laboratory SCC testing, it pointed out the fact that TGSCC of pipeline steels could be induced in dilute aqueous solutions at different $\mathrm{pH}$ values. Therefore, special attention should be done to the mechanical parameters, specially the strain rate at the crack tip (Gabeta et al., 2001).

The present work investigate soil induced cracking susceptibility of API 5L grade steels. Physical, chemical and bacteriological analyses of different soils were performed in order to obtain corrosion index, as proposed by Steinrath. Based on these results, cracking susceptibility was estimated by using slow strain rate testing (SSRT). Anodic polarization was carried out in order to provide an electrochemical basis to explain the results of SSRT. 


\section{Nomenclature}

$\begin{array}{ll}E_{\text {corr }} & =\text { Corrosion Potential } \\ H E & =\text { Hydrogen embrittlement } \\ I G S C C & =\text { Intergranular cracking } \\ N S 4 & =\text { Synthetic soil solution } \\ S C C & =\text { Stress corrosion cracking } \\ S E M & =\text { Scanning electron microscopy } \\ S R B & =\text { Sulphate reduction bacteria } \\ S S R T & =\text { Slow strain rate test } \\ T G S C C & =\text { Transgranular cracking }\end{array}$

\section{Experimental}

The following steels were carried out, API 5L X46, X60 and X80 (API 5L, 2000). Their chemical composition is presented on Tab. 1. Ferritic matrix with lamellar perlite phases was observed for API 5L X46 and X60 steels, and Martensitic-bainitic structure was observed for API 5L X80 steel.

The experimental tests were developed according to the following steps:

1. Collection of soil samples and field measurements.

2. Physical-chemical analyses of the soil samples.

3. Polarization curves with soil solutions.

4. Slow strain rate testing.

5. Optical and electronic microscopy.

The following solutions were used to carry out electrochemical polarization tests and SSRT:

6. Standard synthetic soil solution, called NS4 solution, used to simulate a synthetic soil purged with a $\mathrm{N} 2$ and $5 \% \mathrm{CO} 2$ mixture for $\mathrm{pH}$ adjustment within the range 6.7 and 7.0. The composition is $(\mathrm{g} / \mathrm{l}): \mathrm{KCl}: 0.122, \mathrm{NaHCO} 3: 0.483, \mathrm{CaCl} 2$ : 0.093 and MgSO4: 0.131 (Parkins et al., 1994).

7. Soil solutions produced from solid soil samples.

Soil samples were collected at the interface pipeline-soil of a buried pipeline. The solution obtained is similar to the electrolyte formed by the soil with water saturation. In that case, it is assumed that all existing compounds in the soil - like chloride and sulfate will affect the electrochemical behavior of the soil solution, as well as the $\mathrm{pH}$ of this solution that will represent the $\mathrm{pH}$ of the groundwater in contact with the pipeline. In fact, Nelf et al. (2005) showed that when the soil contains more chloride or carbonates, some specifics corrosion products are formed, such as alkaganeite, oxychlorides and siderite. In addition, Gupta (1979) related that the maximum corrosivity of soils, in general, has $65 \%$ of moisture. In this work, it was used a saturated soil solution with $100 \%$ of moisture.

The following in situ measurements were carried out:

8. Soil resistivity

9. Redox potential

10. Electrode potential

Results of physical, chemical and bacteriological analysis of the soils are shown on Tab. 2. The parameters were selected in accordance with the Steinrath proposition (Souza and Olivier, 2002; and Trabanelli et al., 1972), Tab. 3.

Anodic and cathodic polarization curves were obtained with the same solutions previously described. The effect of oxygen was evaluated in aerated and deaerated conditions in soil samples. Therefore, pure nitrogen was used to extract the oxygen.

Slow strain rate tests were carried out with $9 \times 10^{-6}$ and $9 \times 10^{-7}$ strain rate and with the following experimental conditions:

11. Air - used to simulate an inert environment.

12. Free corrosion potential $\left(\mathrm{E}_{\mathrm{cor}}\right)$.
13. $100 \mathrm{mV}$ below the corrosion potential.

14. $300 \mathrm{mV}$ below the corrosion potential.

Three electrodes cell was used with platinum as counter electrode and copper sulphate as reference electrode. A potentiostat was used to impose the cathodic potentials. The values of fracture time, elongation and reduction of cross sectional areas were calculated. The analyses of the fracture surface and lateral view were made by optical and scanning electron microscopy (SEM).

Table 1. Chemical composition (wt. \%) of the API $5 \mathrm{~L} X 46, \mathrm{X} 60$ and $\mathrm{X} 80$ steels.

\begin{tabular}{|c|c|c|c|c|c|c|c|c|}
\hline \multirow{2}{*}{ Steel } & \multicolumn{7}{|c|}{ Composition (wt. \%) } \\
\cline { 2 - 9 } & $\mathrm{C}$ & $\mathrm{Mn}$ & $\mathrm{Si}$ & $\mathrm{Cr}$ & $\mathrm{Ni}$ & $\mathrm{Mo}$ & $\mathrm{S}$ & $\mathrm{P}$ \\
\hline API X46 & 0.25 & 1.28 & 0.34 & 0.02 & 0.01 & 0.03 & 0.009 & 0.014 \\
\hline API X60 & 0.12 & 1.42 & 0.29 & 0.02 & 0.02 & 0.01 & 0.009 & 0.021 \\
\hline API X80 & 0.05 & 1.75 & 0.17 & 0.21 & 0.02 & 0.17 & 0.005 & 0.018 \\
\hline
\end{tabular}

Table 2. Physical-chemical and bacteriological analyses of the soil samples collected.

\begin{tabular}{|c|c|c|c|c|c|}
\hline \multirow{2}{*}{ Physical-Chemical Parameter } & \multicolumn{5}{|c|}{ Collect point } \\
\cline { 2 - 6 } & A & B & C & D & E \\
\hline Resistivity $($ ohms*cm) & 320000 & 57000 & 54000 & 45000 & 10000 \\
\hline Eredox $(\mathrm{HNE})$ & 503 & 466 & 426 & 423 & 366 \\
\hline $\mathrm{pH}$ & 5.6 & 5 & 5.3 & 5.1 & 5.6 \\
\hline Humidity $(\%)$ & 21 & 30 & 25 & 31 & 23 \\
\hline $\mathrm{Cl}-(\mathrm{mg} / \mathrm{Kg})$ & 55.3 & 45 & 37 & 12.3 & 45.6 \\
\hline SO4-2 $(\mathrm{mg} / \mathrm{Kg})$ & 6.2 & 70 & 12 & 6 & 150.2 \\
\hline S2- $(\mathrm{mg} / \mathrm{Kg})$ & 18.9 & 5.8 & 78 & 15.9 & 35.2 \\
\hline SRB $(\mathrm{MPN} / \mathrm{g})$ & 95 & ---- & 150 & 45 & 1400 \\
\hline Temperature $\left({ }^{\circ} \mathrm{C}\right)$ & 25 & 26 & 25.5 & 27 & 26 \\
\hline
\end{tabular}

Table 3. Corrosiveness indexes of Steinrath and modified Steinrath based on the physical-chemical and bacteriological analyses of the soil samples collected.

\begin{tabular}{|c|c|c|c|c|c|}
\hline \multirow{2}{*}{ Index } & \multicolumn{5}{|c|}{ Collect points } \\
\cline { 2 - 6 } & A & B & C & D & E \\
\hline Steinrath & -3 & -3 & -3 & -3 & -7 \\
\hline Modified Steinrath & -5 & -3 & -5 & -5 & -9 \\
\hline
\end{tabular}

\section{Results}

Five points along the pipeline were selected to collect the soil samples and to perform in situ measurements. Their Steinrath indexes are indicated on Tab. 3. The soil E exhibited the lowest numeric corrosion index. Then, it was chosen for SSRT because of its most corrosivity.

Typical polarization curves obtained for soil and NS4 solutions are presented on Fig. 1. Equilibrium potentials for hydrogen reduction/oxidation reaction and $\mathrm{Fe} / \mathrm{Fe}^{2+}$ are also indicated. Free corrosion potentials are listed on Tab. 4. 


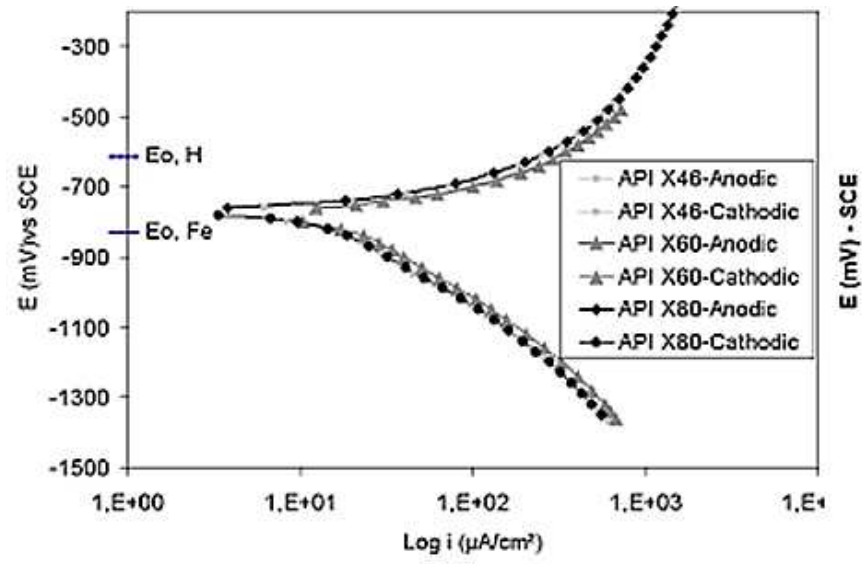

(a)

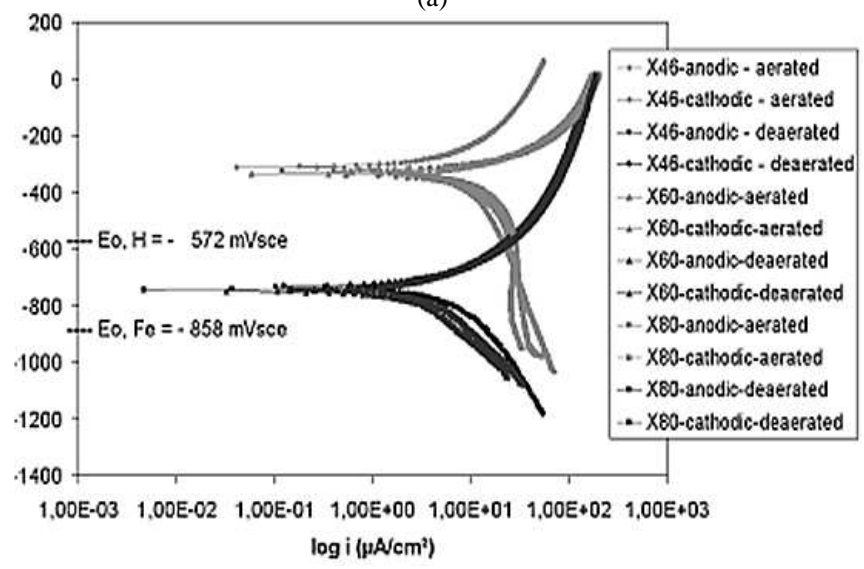

(b)

Figure 1. Anodic and cathodic polarization curves of API $5 \mathrm{~L}$ X46 steel, (a) NS4 solutions deaerated with $5 \% \quad \mathrm{CO}_{2}$ and $\mathrm{N}_{2}$ gas. (b) Aerated and deaerated soil solutions, obtained from soil $\mathrm{E}$.

Table 4. Corrosion Potentials of API $5 \mathrm{~L} X 46, \mathrm{X} 60$ and $X 80$ steels in NS4 deaerated solution, aerated and deaerated soil solutions.

\begin{tabular}{|c|c|c|c|c|c|c|c|}
\hline \multirow{3}{*}{ Steel } & \multirow{3}{*}{ Conditions } & \multicolumn{6}{|c|}{$\mathbf{E}_{\text {corr }}(\mathrm{mV}) \times \mathrm{SCE}$} \\
\hline & & \multicolumn{5}{|c|}{ Soil solutions } & \multirow{2}{*}{$\begin{array}{c}\text { NS4 } \\
\text { solution }\end{array}$} \\
\hline & & $\mathbf{A}$ & $\mathbf{B}$ & $\mathbf{C}$ & D & $\mathbf{E}$ & \\
\hline \multirow{2}{*}{ API X46 } & Aerated & -344 & -292 & -280 & -274 & -298 & --- \\
\hline & Deaerated & -736 & -749 & -687 & -750 & -727 & -774 \\
\hline \multirow{2}{*}{ API X60 } & Aerated & -257 & -336 & -288 & -310 & -363 & ---- \\
\hline & Deaerated & -730 & -745 & -744 & -750 & -750 & -778 \\
\hline \multirow{2}{*}{ API X80 } & Aerated & -253 & -325 & -299 & -288 & -334 & ---- \\
\hline & Deaerated & -732 & -750 & -752 & -738 & -756 & -774 \\
\hline
\end{tabular}

Anodic dissolution at the corrosion potential was observed in both solutions. The behavior of the materials in soil samples and NS4 solution was similar. It suggests that NS4 solution can be representative of a synthetic soil solution. Electrode potentials measured in deaerated solutions were always below the equilibrium potential $\mathrm{H} / \mathrm{H}^{+}$, based on Pourbaix diagram (Pourbaix, 1963), corresponding to the system $\mathrm{Fe} / \mathrm{H}_{2} \mathrm{O}$ at $25^{\circ} \mathrm{C}$. Then, it is possible to conclude that spontaneous hydrogen reduction would occur, from a thermodynamic point of view. The effect of oxygen was more evident in soil solutions. The potential shift for more cathodic values was about $300 \mathrm{mV}$ when the electrochemical cell was purged with pure $\mathrm{N}_{2}$.
Corresponding corrosion potential in deaerated condition, equilibrium potentials for hydrogen reduction/oxidation reaction and the difference between those potentials for each environment are listed on Tab. 5.

Table 5. Corrosion potentials in deaerated condition of NS4 and E Soil solution, $\mathrm{H} / \mathrm{H}^{+}$potentials, and difference between those potentials with potential of $\mathrm{H} / \mathrm{H}^{+}$.

\begin{tabular}{|c|c|c|c|c|}
\hline Solution & $\begin{array}{c}\text { Steel API } \\
\text { 5L }\end{array}$ & $\begin{array}{c}\text { Corrosion } \\
\text { Potential mV } \\
\text { (SCE) }\end{array}$ & $\begin{array}{c}\text { Pot. Equil. } \\
\text { H/H } / \mathbf{H}^{+} \\
\mathrm{mV}(\mathrm{SCE})\end{array}$ & $\Delta_{\mathbf{H}}=\mathbf{E c o r}-\mathbf{E H} / \mathbf{H}+$ \\
\hline \multirow{3}{*}{$\begin{array}{c}\text { NS4 } \\
\text { solution }\end{array}$} & X46 & -704 & \multirow{3}{*}{-637} & -67 \\
\hline & X60 & -708 & & -71 \\
\hline & X80 & -704 & & -67 \\
\hline \multirow{3}{*}{$\begin{array}{c}\text { Soil solution } \\
\text { E }\end{array}$} & X46 & -750 & \multirow{3}{*}{-572} & -178 \\
\hline & X60 & -750 & & -178 \\
\hline & X80 & -756 & & -184 \\
\hline
\end{tabular}

Typical stress vs. strain curves obtained for API 5L X46 steel are shown on Fig. 2, with the following conditions: (a) NS4 solutions with $9 \times 10^{-6} \mathrm{~s}^{-1}$ strain rate, (b) soil solutions with $9 \times 10^{-6} \mathrm{~s}^{-1}$ strain rate, and (c) soil solutions with $9 \times 10^{-6} \mathrm{~s}^{-1}$ and $9 \times 10^{-7} \mathrm{~s}^{-1}$ strain rate. The comparison with the curve obtained in air indicates a clear reduction of ductility (average values on Tab. 6). A direct comparison of these parameters is presented on Fig. 3.

The loss of ductility was observed in all tests when lower strain rates were used. The Tab. 7 presents average results of elongation and reduction of area measured after testing. A comparative analysis of these parameters is presented on Fig. 4.

The Fig. 5 shows the lateral surfaces of the SSRT specimens. API 5L X46, X60 and X80 steels were tested in air, immersed in NS4 deaerated solution and in soil deaerated solution, with the following conditions: (A) air tested, (B) $\mathrm{E}_{\text {corr }}-300 \mathrm{mV}$ in NS4 solution and $(\mathrm{C}) \mathrm{E}_{\text {corr }}-300 \mathrm{mV}$ in soil solution. The incidence of brittle fracture, decreasing RA\% and secondary cracks were evident when tested in solution at the potential equal to OCP minus $300 \mathrm{mV}$.

In the Figs. 6 and 7, the corresponding fracture surfaces of the specimens are shown. The presence of dimples is predominant at the steels that were tested in inert environment. On the other hand, the fracture surfaces of specimens tested in solution at the potential of $300 \mathrm{mV}$ below the OCP exhibited brittle fracture morphology. This difference was more evident with API X60 and API X80 steels. 


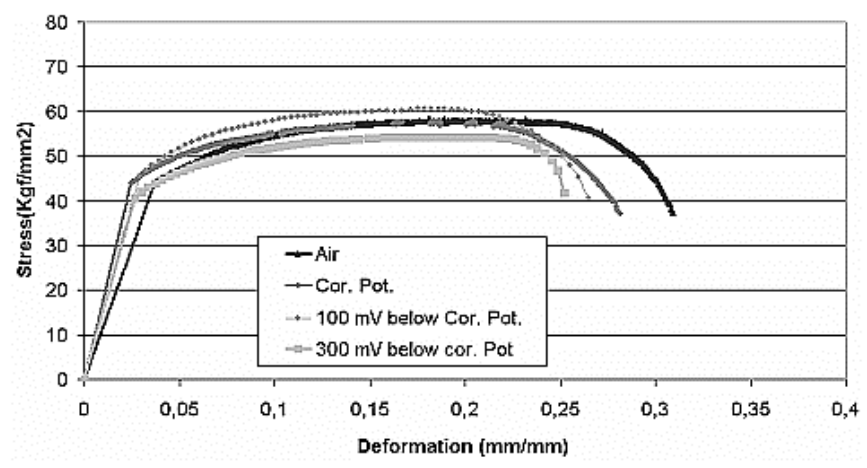

(a)

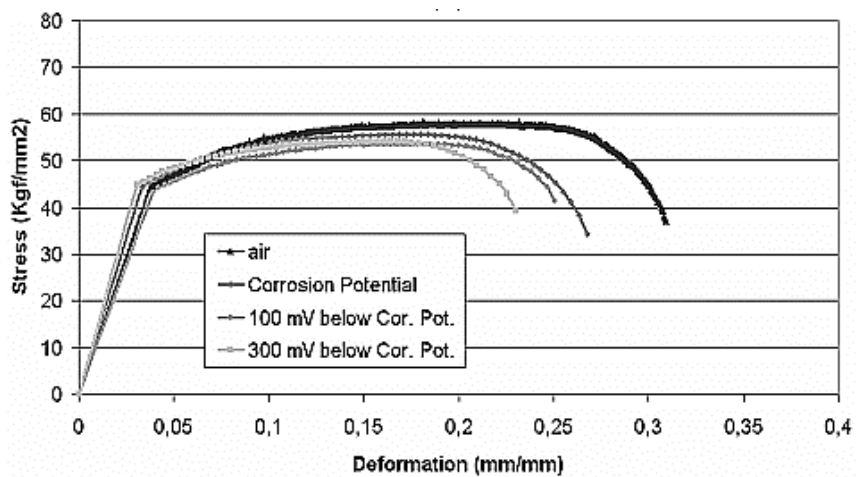

(b)

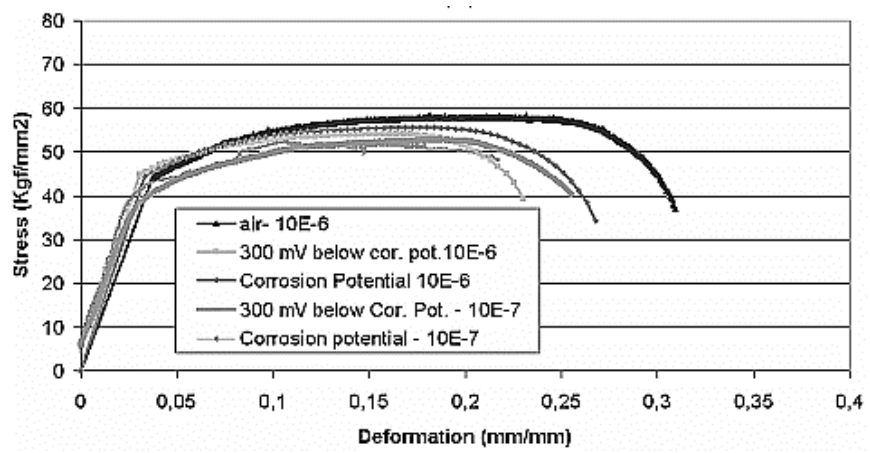

(c)

Figure 2. Typical stress - strain curves obtained from SSRT for API 5L X46 steel, (a) NS4 solutions with $9 \times 10^{-6} \mathrm{~s}^{-1}$ of strain rate, (b) soil solutions with $9 \times 10^{-6} \mathrm{~s}^{-1}$ of strain rate, and (c) soil solutions with $9 \times 10^{-6} \mathrm{~s}^{-1}$ and $9 \times$ $10^{-7} \mathrm{~s}^{-1}$ of strain rate.

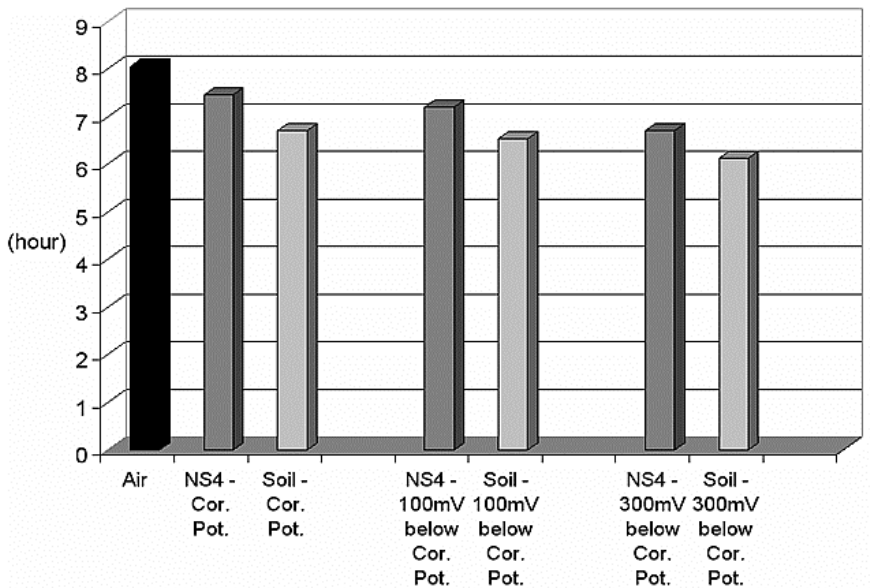

(a)

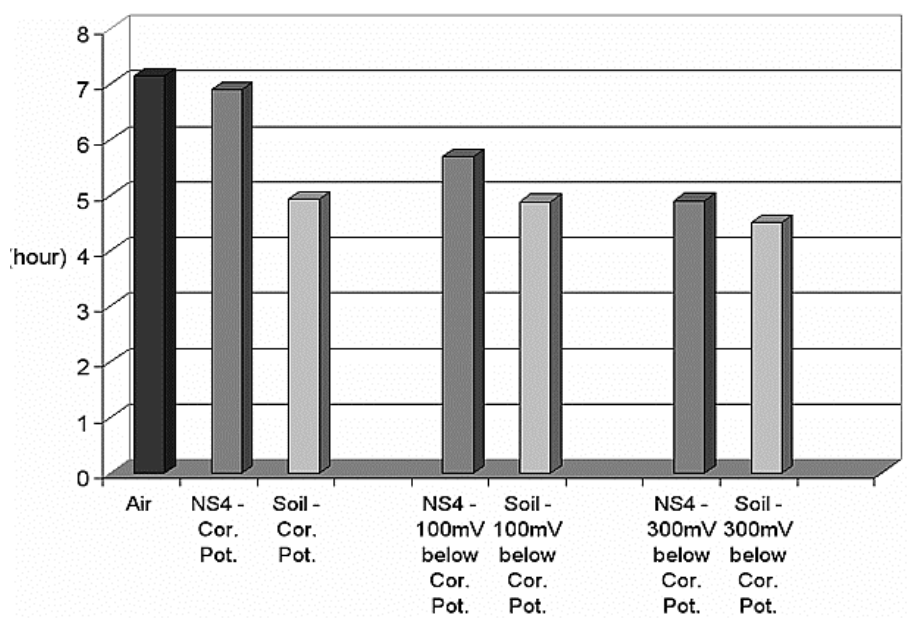

(b)

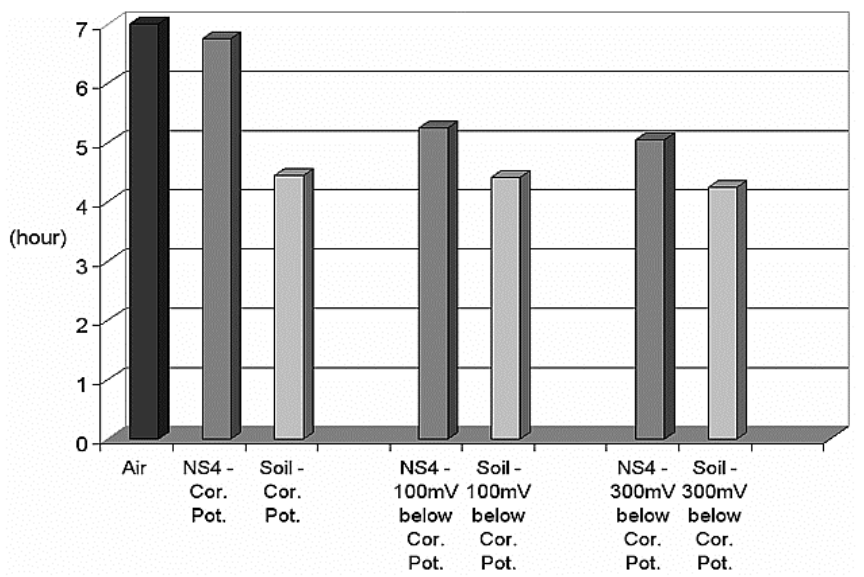

(c)

Figure 3. Time to failure of API 5L (a) X46, (b) X60 and (c) X80 steels tested with SSRT in following conditions: air, deaerated NS4 solution and deaerated soil solution at the corrosion potential, $100 \mathrm{mV}$ and $300 \mathrm{mV}$ below the corrosion potential, and $9 \times 10^{-6} \mathrm{~s}^{-1}$ strain rate. 
Table 6. Average of the results obtained from Slow Strain Rate tests with API 5L X46, X60 and X80 steels in deaerated NS4 solution and deaerated soil solution with $9 \times 10^{-6} \mathrm{~s}^{-1}$ of strain rate.

\begin{tabular}{|c|c|c|c|c|c|c|c|c|c|c|}
\hline \multirow{2}{*}{$\begin{array}{c}\text { Test } \\
\text { condition }\end{array}$} & \multicolumn{3}{|c|}{ API 5L X46 Steel } & \multicolumn{3}{c|}{ API 5L X60 Steel } & \multicolumn{3}{c|}{ API 5L X80 Steel } \\
\cline { 2 - 10 } & $\boldsymbol{\varepsilon}(\boldsymbol{\%})$ & $\begin{array}{c}\text { Area } \\
\text { Reduction } \\
(\%)\end{array}$ & $\begin{array}{c}\text { Time } \\
\text { Failure } \\
(\mathbf{h})\end{array}$ & $\boldsymbol{\varepsilon}(\boldsymbol{\%})$ & $\begin{array}{c}\text { Area } \\
\text { Reduction } \\
(\boldsymbol{\%})\end{array}$ & $\begin{array}{c}\text { Time } \\
\text { failure } \\
(\mathbf{h})\end{array}$ & $\boldsymbol{\varepsilon}(\boldsymbol{\%})$ & $\begin{array}{c}\text { Area } \\
\text { Reduction } \\
(\%)\end{array}$ & $\begin{array}{c}\text { Time } \\
\text { failure } \\
(\mathbf{h})\end{array}$ \\
\hline A & 29.90 & 48.50 & 8.05 & 21.40 & 54.00 & 7.15 & 18.00 & 60.00 & 7.00 \\
\hline & \multicolumn{3}{|c|}{ NS4 solution } & \multicolumn{3}{c|}{ NS4 solution } & \multicolumn{3}{c|}{ NS4 solution } \\
\hline B & 27.70 & 43.50 & 7.45 & 20.60 & 47.00 & 6.90 & 17.20 & 53.00 & 6.75 \\
\hline C & 26.70 & 35.00 & 7.20 & 16.90 & 30.00 & 5.70 & 13.30 & 29.50 & 5.25 \\
\hline D & 25.20 & 22.50 & 6.70 & 14.50 & 19.50 & 4.90 & 12.80 & 25.50 & 5.05 \\
\hline & \multicolumn{3}{|c|}{ Soil solution } & \multicolumn{3}{|c|}{ Soil solution } & \multicolumn{3}{|c|}{ Soil solution } \\
\hline B & 26.60 & 41.00 & 6.71 & 17.80 & 40.00 & 4.92 & 15.50 & 47.60 & 4.45 \\
\hline C & 24.80 & 30.20 & 6.54 & 17.30 & 39.00 & 4.88 & 15.10 & 48.10 & 4.41 \\
\hline D & 22.70 & 20.00 & 6.13 & 14.50 & 26.05 & 4.50 & 14.30 & 35.00 & 4.25 \\
\hline
\end{tabular}
(A): Air test
(B): Corrosion Potential ( $\left.\mathrm{E}_{\text {corr }}\right)$
(C): $100 \mathrm{mV}$ below $\mathrm{E}_{\text {corr }}$

(D): $300 \mathrm{mV}$ below $\mathrm{E}_{\text {corr }}$

Table 7. Average of the results obtained from Slow Strain Rate tests with API $5 \mathrm{~L}$ grade X46 steel in deaerated soil solution, with $9 \times 10^{-6}$ and $9 \times 10^{-7} \mathrm{~s}^{-1}$ of strain rate.

\begin{tabular}{|c|c|c|c|c|}
\hline \multirow{2}{*}{ Test Condition } & \multicolumn{2}{|c|}{\begin{tabular}{|l|} 
Elongation \\
$(\%)$ \\
\end{tabular}} & \multicolumn{2}{|c|}{ Area Reduction (\%) } \\
\hline & $9 * 10^{-6} \mathrm{~s}^{-1}$ & $9 * 10^{-7} \mathrm{~s}^{-1}$ & $9 * 10^{-6} \mathrm{~s}^{-1}$ & $9 * 10^{-7} \mathrm{~s}^{-1}$ \\
\hline Soil test: Ecorr & 26.6 & 25.7 & 41 & 36 \\
\hline $\begin{array}{l}\text { Soil test: } \\
\text { Ecorr - } 300 \mathrm{mV}\end{array}$ & 22.7 & 21.8 & 20 & 15 \\
\hline
\end{tabular}

Figure 8 presents in (a) precipitates of iron carbonate formed at the surface of the specimens of an API 5L X46 steel, tested in deaerated NS4 solution at $300 \mathrm{mV}$ below $\mathrm{E}_{\text {corr }}\left(9 \times 10^{-7} \mathrm{~s}^{-1}\right.$ strain rate). The absence of corrosion products was evident. The presence of corrosion products was only detected when the specimens were tested at free corrosion potential. This behavior was reproduced in both solutions, as shown in Fig. 8b.

Optical microscopy of the internal longitudinal cross section of the specimens is shown in the Fig. 9. Therefore, transgranular cracking was detected in all specimens tested in cathodic conditions of corrosion potential minus $300 \mathrm{mV}$.

Correlation between electrode potential and the results obtained from SSRT are indicated in Fig. 10. Equilibrium potential for the reaction $\mathrm{Fe} / \mathrm{Fe}^{2+}$ is indicated. It is possible to observe that the electrode potentials obtained were always below the $\mathrm{H} / \mathrm{H}^{+}$ equilibrium potential and above the $\mathrm{Fe} / \mathrm{Fe}^{2+}$ equilibrium potential.

\section{Discussion}

Five soils samples were collected. But, only the soil considered the most aggressive was used at SSRT (Tabs. 2 and 3). Two methods were used to determine the soil aggressiveness. The first one was through anodic polarization curves (Fig. 1). In that case, all soil samples presented the same electrochemical behavior. Consequently, it was not possible to rank the soils based on the electrochemical characteristics. The second method used was the Steinrath (Trabanelli et al., 1972) and modified Steinrath indexes (Souza and Olivier, 2002), which revealed to be the most accurate method to rank soil corrosiveness. The data presented in Tabs. 2 and 3 show that the most aggressive soil was sample "E". The low "in situ" resistivity, low redox potential, the presence of sulphate and sulphate reducing bacteria were the main factors that contributed to the more negative index.

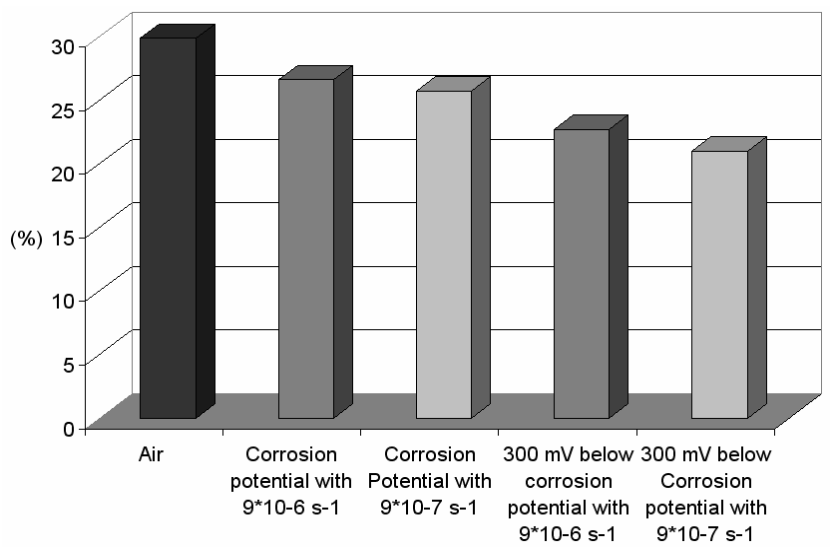

(a)

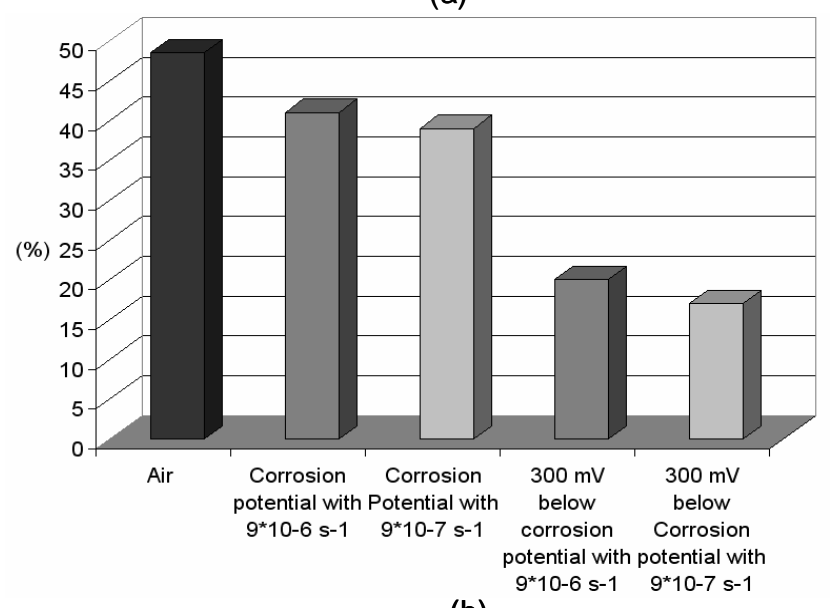

(b)

Figure 4. Mechanical parameters of API $5 \mathrm{~L}$ grade X46 steel tested in SSRT in air, deaerated soil solution at corrosion potential and $300 \mathrm{mV}$ below the corrosion potential, with $9^{*} 10^{-6} \mathrm{~s}^{-1}$ and $9^{\star} 10^{-7} \mathrm{~s}^{-1}$ of strain rate. (a) Total elongation, and (b) Area reduction. 

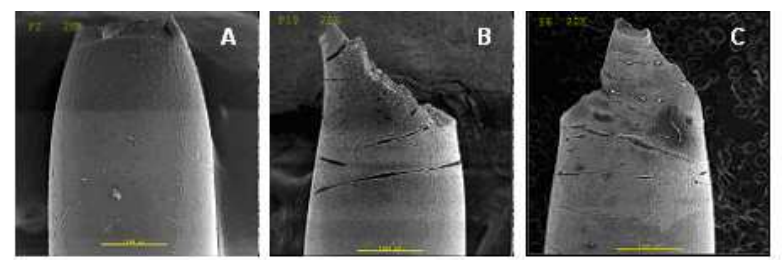

Figure 5. SEM images showing the surface morphology of API 5L X60 steel near to the necking site in the gauge section of tensile sample. (A) Air, (B) NS4 solution with applied potential of $300 \mathrm{mV}$ below the corrosion potential, and (C) Soil solution in the same applied potential with NS4 solution.
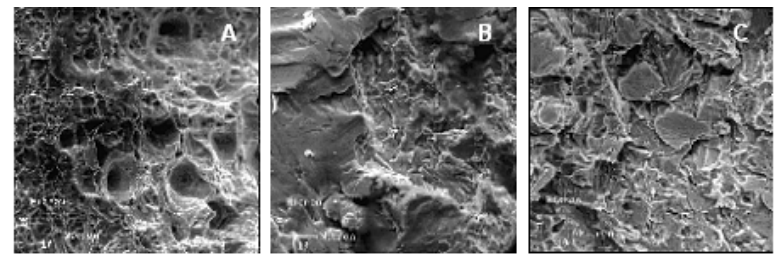

Figure 6. API $5 \mathrm{~L}$ X60 steel - SEM micrograph of fracture surface of SSRT specimen tested in both solutions. (A) Air, (B) NS4 solution with applied potential of $300 \mathrm{mV}$ below the corrosion potential, and (C) Soil solution with the same applied potential; all images: A, B and C with 2000x.
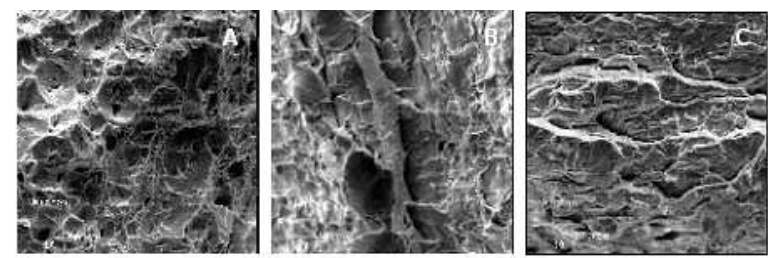

Figure 7. API 5L X80 steel - SEM micrograph of fracture surface of SSRT specimen tested in both solutions. (A) Air, (B) NS4 solution with applied potential of $300 \mathrm{mV}$ below the corrosion potential, and (C) Soil solution with the same applied potential; all images: A, B and C with 2000x.

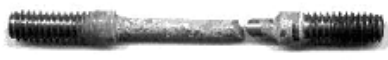

(a)

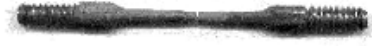

(b)
Figure 8. API $5 \mathrm{~L}$ grade X46 steel - SSRT, (a) Specimen tested in NS4 solution with $9 \times 10^{-7} \mathrm{~s}^{-1}$ of strain rate and potential imposed of the $300 \mathrm{mV}$ below the corrosion potential, and (b) Specimen tested in soil solution with strain rate of $9 \times 10^{-6} \mathrm{~s}^{-1}$ and at the corrosion potential.

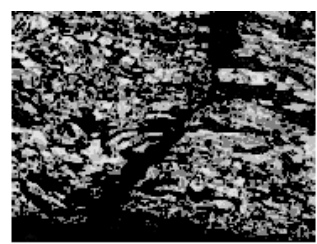

Figure 9. Optical microscopy - Longitudinal Section of API $5 \mathrm{~L}$ X46 steel tested in soil solution, showing the Transgranular crack path followed by a secondary crack.
The first point to be discussed is the open circuit potential (OCP) obtained in soil solutions. According to the $\mathrm{E} x \mathrm{pH}$ diagram, as proposed by Pourbaix (1963) to explain the thermodynamic behavior of $\mathrm{Fe}$ in $\mathrm{H}_{2} \mathrm{O}$ at $25{ }^{\circ} \mathrm{C}$, the electrode potentials measured are within the corrosion area (Tabs. 4 and 5). A difference between aerated and deaerated conditions can be observed. When oxygen is removed from the system the electrode potential changes to a value below the equilibrium potential $\mathrm{H} / \mathrm{H}^{+}$. Consequently, it can be assumed that in soil solution without oxygen, corrosion is associated to hydrogen reduction.

Another interesting aspect to point out is that the NS4 solution and the soil solution presented similar electrochemical behavior. This fact supports the idea that NS4 solution could be used to represent the corrosive properties of a specific near-neutral soil, at the same $\mathrm{pH}$ value. All steels presented a clear decreasing of ductility in both solutions when a more cathodic potential was imposed (Fig. 2). The tests carried out with a potential applied of $300 \mathrm{mV}$ below the corrosion potential in both solutions showed that the total elongation of SSRT test reduced. In addition, presence of secondary cracks, precipitation of cathodic products and loss of ductility were also observed in this condition (Figs. 5, 6 and 7).
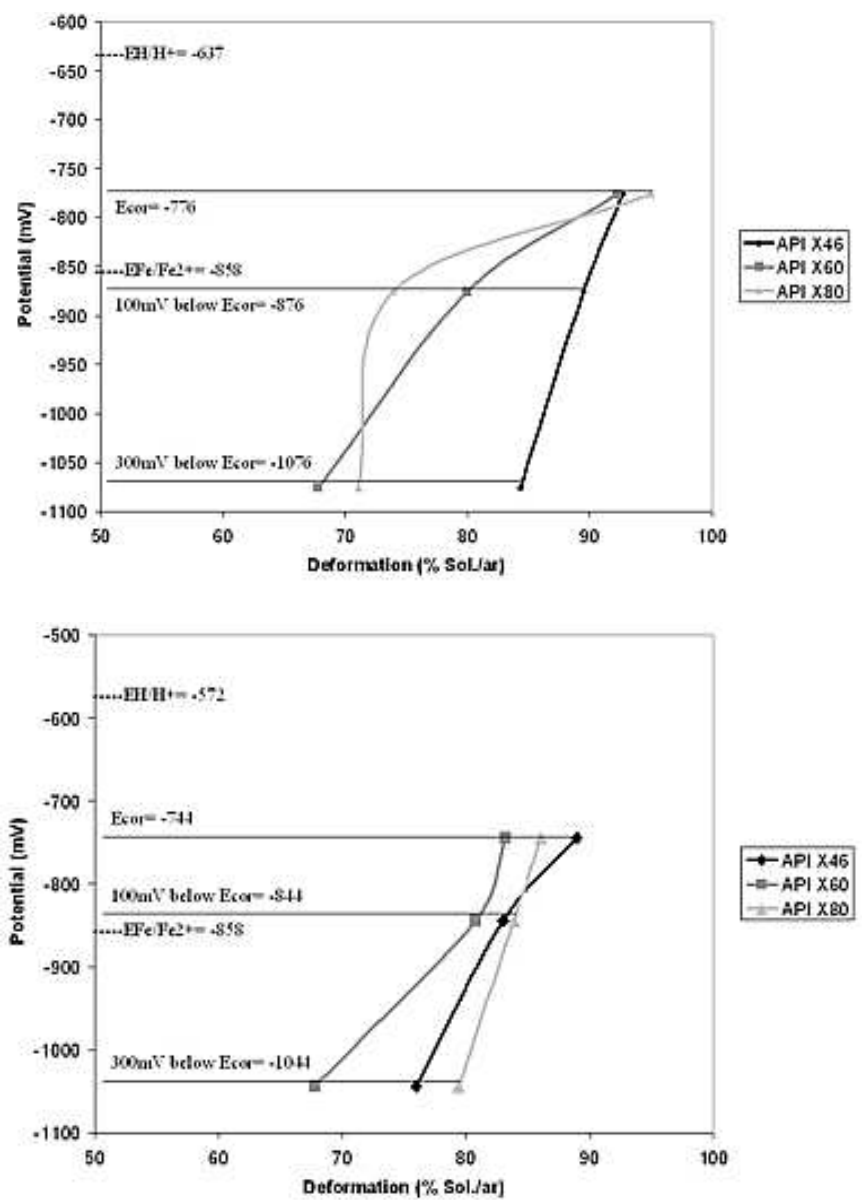

Figure 10. Potential versus deformation, (a) NS4 Solution/air and (b) Soil Solution/air.

The loss of ductility promoted by more cathodic potentials can be explained from a thermodynamic analysis of the corrosion potentials registered in NS4, and soil solutions. Analyses based on 
the $\mathrm{E}$ vs. $\mathrm{pH}$ equilibrium diagram reveal that the corrosion potentials of all steels in both solutions are positioned in the corrosion domain of iron and below the corresponding equilibrium potential for hydrogen reduction/oxidation (Tab. 5). Therefore, it can be assumed that the materials suffer a combined action of anodic dissolution and hydrogen reduction, which can cause steel embrittlement. Anodic dissolution was evident when the specimens were tested without the imposition of a cathodic potential (Fig. 9).

However, anodic dissolution seems to have a secondary contribution to the deterioration mechanism. Based on the results of SSRT carried out at cathodic potentials, it was evident that the ductility was reduced and the incidence of secondary cracks was more severe despite of the absence of corrosion products (Fig. 8). Suppression of anodic dissolution was possible when the cathodic potentials (100 and $300 \mathrm{mV}$ below corrosion potential) were positioned within the immunity domain of the $\mathrm{E}$ vs. $\mathrm{pH}$ diagram. Therefore, the secondary cracks and the loss of ductility are attributed to hydrogen embrittlement, since the anodic dissolution was suppressed. This behavior can be confirmed by the Figs. 5 to 7 (B and $\mathrm{C}$ ), where the presence of cleavage at the fracture surface, secondary cracks and loss of ductility are typical features of brittle fracture. The original fracture mechanism of the materials is shown in Figs. 5 to 7 (A), where the presence of dimples is typical when the specimens are tested in air, suggesting a ductile fracture mechanism.

On the other hand, the increasing number of secondary cracks seems to be in contradiction with the previous explanation. Secondary surface cracking is commonly associated to anodic dissolution. However, this cracking mechanism can be originated by hydrogen uptake and its interaction with the included material.

These results are in accordance with the results reported by Parkins et al. (1994) and TransCanada (1996). They confirm the mechanism of SCC - near neutral $\mathrm{pH}$. This SCC process is characterized by a transgranular cracking morphology (Fig. 9) and a conjoint effect of anodic dissolution and hydrogen embrittlement. All steels presented secondary cracking and loss of ductility when cathodic potentials were imposed in the SSRT test (Fig. 5). However the presence of iron carbonate was not evident in SSRT with strain rate of $9 \times 10^{-6} \mathrm{~s}^{-1}$.

In relation to the SSRT tests with a lower strain rate $\left(9 \times 10^{-7} \mathrm{~s}^{-1}\right)$, it was possible to observe the presence of iron carbonate precipitated at the surface of steels carried out with cathodic conditions in NS4 solution (Fig. 8a). However, when the same test was carried out in soil solution, using the same strain rate, precipitation of iron carbonate did not occur. These results can be explained probably by the presence of $\mathrm{NaHCO}_{3}$ in the NS4 solution.

Morphology of cracking observed at strain rate of $9 \times 10^{-7} \mathrm{~s}^{-1}$ was similar to observed at strain rate of $910^{-6} \mathrm{~s}^{-1}$. However, the tests with strain rate of $9 \times 10^{-7} \mathrm{~s}^{-1}$ had more severe loss of ductility than the tests with strain rate of $9 \times 10^{-6} \mathrm{~s}^{-1}$ (Figs. 2c, 4 and Tab. 7). The same thermodynamics analyses can be suggested to interpret this phenomenon. This behavior can be attributed to hydrogen diffusion because of the longer time exposure that they were provided. Yan and Weng (2006) have shown that the API X70 steel presented susceptibility to hydrogen absorption.

Results obtained in NS4 solution in comparison to soil solution indicate a more severe loss of ductility in the soil solution (Figs. 2a, 2b, 3 and Tab. 6). Two different aspects can be mentioned to explain this behavior. The first one is related to the soil solutions that were more acid than NS4 solution. The second one is the difference between the cathodic potentials imposed in each solution and the equilibrium potential for hydrogen reduction. It is reasonable to suggest that the driving force for hydrogen reduction is higher in soil solution $\left(\mathrm{E}_{\mathrm{SCE}}=-750 \mathrm{mV}\right)$ than in NS4 solution $\left(\mathrm{E}_{\mathrm{SCE}}=-704 \mathrm{mV}\right)$. Consequently, hydrogen effects would be more intense in soil solution (Tab. 5 and Fig. 1), as suggested from the analyses of the corrosion potential. The fracture surface of the steel tested in soil sample at the potential of $300 \mathrm{mV}$ below Ecorr, exhibited only cleavage like fracture morphology (Figs. $6 \mathrm{c}$ and $7 \mathrm{c}$ ). However, the same material tested in the same condition in the NS4 solution exhibited a few quantities of dimples, despite of the predominant cleavage like fracture (Figs. $6 \mathrm{~b}$ and $7 \mathrm{~b}$ ).

A comparison among the materials tested suggests that the API X60 steel presented a more intense deterioration due probably to the higher inclusion content in this steel (Fig. 10). Elboujdaini et al. (2000) obtained similar results testing an API 5L X65 steel in near neutral $\mathrm{pH}$ solution. According to this author, crack initiation and propagation will depend on several factors, such as pitting morphology, localized dissolution of inclusions and plastic deformation, despite the fundamental contribution to be caused by electrochemical reactions, like anodic dissolution. The influence of discontinuities acting as stress raisers is pointed out. Smialowska and Lunarska (1981) related that the nonmetallic inclusions present in steels as impurities adversely affect the corrosion resistance of steels. This is true for both general and localized corrosion mechanisms, like pitting corrosion, stress corrosion cracking (SCC), and hydrogen embrittlement (HE).

In this paper, transgranular cracking morphology (Fig. 9) and the adverse influence of cathodic potentials in soil and NS4 solutions are shown. Indication of hydrogen contribution will be confirmed by permeation tests to be carried out using the same steels and environments. The incidence of transgranular cracking was expected since the environments can be considered as near neutral $\mathrm{pH}$ solutions, according to the interpretation presented by Parkins. However, the contribution of different stress stages to TGSCC or IGSCC as proposed by Gabeta et al. (2001) deserves further investigation. Additional SSRT is in progress at COPPE/UFRJ as well as constant load tests are scheduled for the next stages of this research.

\section{Conclusion}

1 The studied materials exhibited a decreasing ductility as long as more cathodic potentials were imposed. This effect was more evident in soil solutions than in NS4 standard solution.

2 The deterioration mechanism is related to the influence of hydrogen. Transgranular cracking occurred even under cathodic conditions where the anodic dissolution of the steel can be considered as negligible.

3 Cracking morphology was similar to the one presented by Parkins to explain soil induced stress corrosion cracking of carbon steel in near neutral $\mathrm{pH}$ conditions.

4 When the specimens were tested using a lower strain rate, $9 \times 10^{-7} \mathrm{~s}^{-1}$, it was possible to observe the presence of iron carbonate precipitated at the specimens surface at cathodic conditions in NS4 solution. However, when the same test was carried out with soil solution, using the same strain rate, precipitation of iron carbonate was not identified. These results can probably be explained by the presence of $\mathrm{NaHCO} 3$ in NS4 solution.

5 The tests with strain rate of $9 \times 10^{-7} \mathrm{~s}^{-1}$ had more severe loss of ductility than the tests with strain rate of $9 \times 10^{-6} \mathrm{~s}^{-1}$. This behavior can be attributed to hydrogen diffusion because of the longer exposure times that they were provided.

\section{Acknowledgement}

This research was financially supported by $\mathrm{CNPq}$ and COPPETEC. 


\section{References} Edition.

API Specification 5L, 2000, "Specification for line pipe", API code, $42^{\text {nd }}$

Benmoussa, A., Hadjel, M. and Traisnel, M., 2006, "Corrosion behavior of API 5L X-60 pipeline steel exposed to near-neutral $\mathrm{pH}$ soil simulating solution", Materials and Corrosion, Vol. 57, pp. 771-777.

Elboujdaini, M., et al., 2000, "Initiation of stress corrosion cracking on $\mathrm{X}-65$ pipeline steels in near-neutral $\mathrm{pH}$ environment", Proceedings of the $3^{\text {rd }}$ International Pipeline Conference, ASME, Calgary, Canada, Vol. 2.

Gabeta, G., et al., 2001, "Strain rate induced stress corrosion cracking in buried pipelines", British Corrosion Journal, Vol. 36, no. 1.

Gomes, J.A.C.P., Bastos, I.N., Costa-Matos, H.S. and Vasconcellos, J.F.V., 2005, "A continuum damage model for the stress corrosion cracking of austenitic stainless steel", Journal of the Brazilian Society of Mechanical Sciences and Engineering, Vol. 27, pp. 186-191, 2005.

GRI Research, 1998, "Stress corrosion cracking mechanisms in pipeline", Pipeline \& Gas Journal.

Gupta, S. K. and Gupta, B. K., 1979, "The critical soil moisture content in the underground corrosion of mild steel", Corrosion Science, Vol. 19, pp. 171-178.

National Energy Board, 1996, report of the inquiry, "Stress corrosion cracking on Canadian oil gas pipelines", Calgary, Canada.
Nelf, D., Dillmann, P., Bellot-Gurlet, L. and Beranger, G., 2005, "Corrosion of iron archaeological artefacts in soil: characterization of the corrosion system", Corrosion Science, Vol. 47, pp. 515-535.

Parkins, R.N., Blanchard, W.K. and Delanty, B.S., 1994, "Transgranular stress corrosion cracking of high-pressure pipelines in contact with solutions of near neutral pH", Corrosion, Vol. 50, no. 5, pp. 394-408.

Pourbaix, M., 1963, "Atlas d'équilibres électrochimiques à $25^{\circ} \mathrm{C}$ ", Publication du Centre Belge D'Étude de la Corrosion (CEBELCOR), Paris.

Smialowska, Z.S., Lunarska, E., 1981, "The effect of sulfide inclusions on the susceptibility of steels to pitting, stress corrosion cracking and hydrogen embrittlement", Materials and Corrosion, Vol. 32, pp. 478-485.

Souza, B.G. and Olivier, J.H.L., 2002, "Circumferential SCC in pipeline due to land creeping", Proceedings of the $4^{\text {th }}$ International Pipeline Conference, ASME, Calgary, Canada, pp.1-9.

Trabanelli, G., Zucchi, F., Arpaia, M., 1972, "Methods of determination of soil corrosiveness with respect to metallic structures", Proceedings of the Chinica Pura ed Applicata, Vol. III, Sezione V, n. 4, pp. 43-59.

Wang, J.Q. and Atrens, A., 2003, "SCC initiation for X65 pipeline steel in the 'high' pH carbonate/bicarbonate solution", Corrosion Science, Vol. 45, pp. 2199-2217.

Yan, M. and Weng, Y., 2006, "Study on hydrogen absorption of pipeline steel under cathodic charging", Corrosion Science, Vol. 48, pp. 432-444.

Zheng, W., 1996, "Pipeline SCC in near neutral pH environment: recent progress", Proceedings of the $1^{\text {st }}$ International Pipeline Conference, ASME, Calgary, Canada, Vol. 1. 